\title{
Hypertension in the West Indies
}

\author{
Gerald A. C. GRell \\ M.B.B.S., F.R.C.P., D.T.M\&H. \\ Department of Medicine, University of the West Indies, Mona, Kingston 7, Jamaica
}

\begin{abstract}
Summary
Hypertension is the most common chronic disease in the West Indies, and is a major health problem today being among the 10 most common causes of death in the English-speaking territories of the region. Most patients have essential hypertension. Renal failure, stroke, and cardiac failure are the most common complications, myocardial infarction being relatively uncommon in black patients.

While an earlier report from the Caribbean suggested that beta-blockers were not effective for treating black hypertensives, recent experience with these drugs show that they are useful particularly when administered along with a diuretic. Betablockers may be required in higher doses than those commonly recommended for patients in Europe and North America, but even small doses of thiazide diuretics are effective in lowering the blood pressure of West Indian hypertensives.

West Indians show a combination of personalistic, naturalistic, and modern medical beliefs, which need to be understood in order to mount effective programmes for the management of hypertension in the community.
\end{abstract}

KEY WORDS: hypertension, West Indians, Caribbean, black hypertensives.

\section{Introduction}

In the Caribbean, as in most 'westernized' countries, blood pressure rises with age. Antia et al. (1980) showed that from the age of 5 years there was a gradual increase in both systolic and diastolic blood pressure of Jamaican children similar to that seen in black children in Nigeria and the U.S.A. (Fig. 1). Earlier studies by Miall and Cochrane (1961) indicated that the rise in systolic and diastolic blood pressure of black Jamaican adults was almost identical to that of age- and sex-matched white subjects in Wales (Fig. 2).

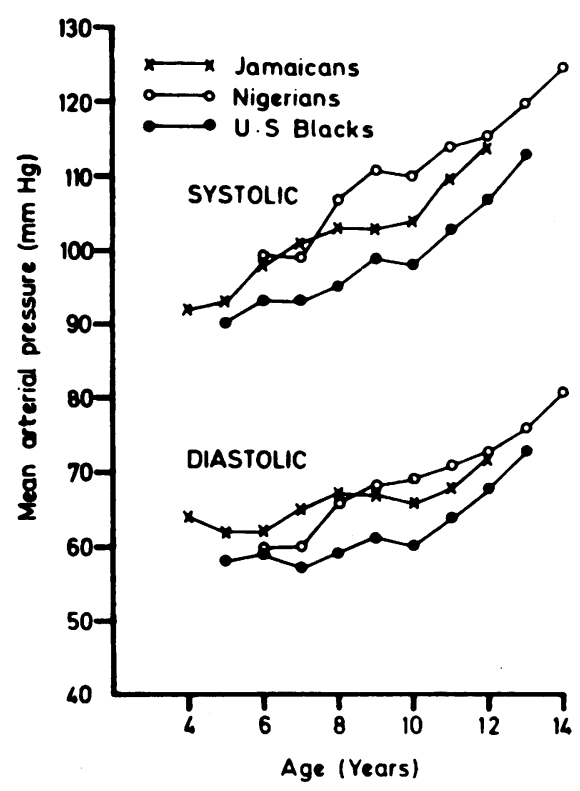

FIG. 1. Mean systolic and diastolic blood pressures of Jamaica Nigerian and U.S. black children [from Antia et al (1980) with. permission of the Editor].

In the U.S.A., it has been shown on screening that hypertension is more common in blacks than white? (HDFP Cooperative Group, 1977), and Sever et at. (1978) in London found that the blood pressure of hypertensive blacks was higher than that of hyper tensive whites. Such studies serve to highlight the importance of ethnic factors in hypertension and indicate that in countries with predominantly black populations such as the West Indies, hypertension is likely to be of major significance.

It is estimated from a review of several surveys i the West Indies that $18-22 \%$ of adults have blood pressures in excess of $160 / 95 \mathrm{mmHg}$ (Grell, 1982). A a consequence of this high prevalence, hypertension and problems directly attributable to it have been 

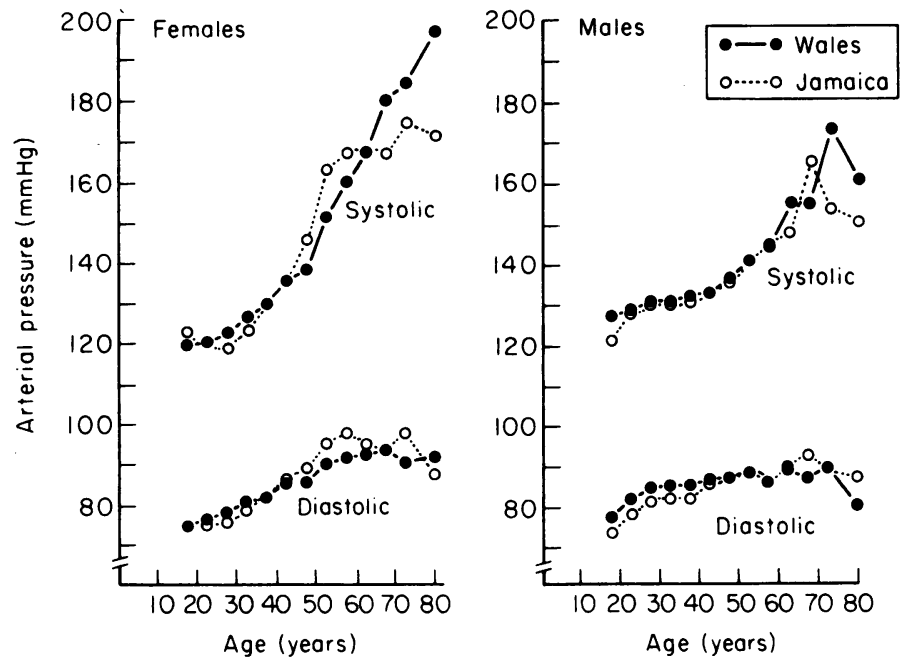

FIG. 2. Mean systolic and diastolic blood pressures in males and females in Wales and Jamaica [from Miall and Cochrane (1961) with the permission of the Editor].

TABLE 1. Principal causes of death* (rate per 100,000 population)

\begin{tabular}{|c|c|c|c|c|c|c|c|}
\hline \multicolumn{2}{|c|}{$\begin{array}{c}\text { Trinidad and Tobago } \\
\text { (1976) }\end{array}$} & \multicolumn{2}{|l|}{$\begin{array}{l}\text { St Lucia } \\
\text { (1976) }\end{array}$} & \multicolumn{2}{|l|}{$\begin{array}{l}\text { Barbados } \\
\text { (1975) }\end{array}$} & \multicolumn{2}{|l|}{$\begin{array}{c}\text { St Kitts and Nevis } \\
\text { (1977) }\end{array}$} \\
\hline $\begin{array}{l}\text { Diseases of the heart } \\
\text { Cerebrovascular } \\
\text { disease } \\
\text { Malignant neoplasms } \\
\text { Diabetes mellitus } \\
\text { Accidents } \\
\text { Influenza and } \\
\text { pneumonia } \\
\text { Enteritis and other } \\
\text { diarrhoeal diseases } \\
\text { Perinatal mortality } \\
\text { Bronchitis, } \\
\text { emphysema and } \\
\text { asthma } \\
\text { Cirrhosis of the liver }\end{array}$ & $\begin{array}{r}169.0 \\
85.9 \\
58.8 \\
55.6 \\
36.8 \\
\\
32.9\end{array}$ & $\begin{array}{l}\text { Cerebrovascular } \\
\text { diseases } \\
\text { Heart diseases } \\
\quad \text { (excluding IHD) } \\
\text { Pneumonia } \\
\quad \text { (excluding viral) } \\
\text { Senility } \\
\text { Ill-defined conditions } \\
\text { Enteritis and other } \\
\text { diarrhoeal diseases } \\
\text { Ischaemia heart } \\
\text { disease (IHD) } \\
\text { Perinatal mortality } \\
\text { Bronchitis, } \\
\text { emphysema, } \\
\text { asthma } \\
\text { Cirrhosis of the liver } \\
\text { Hypertensive disease }\end{array}$ & $\begin{array}{l}66.0 \\
\\
51 \cdot 0 \\
51.0 \\
40.0\end{array}$ & $\begin{array}{l}\text { Heart disease } \\
\text { Cerebrovascular } \\
\quad \text { disease } \\
\text { Malignant neoplasms } \\
\text { Other circulatory } \\
\quad \text { diseases } \\
\text { Hypertensive disease } \\
\text { Pneumonia } \\
\text { Diabetes mellitus } \\
\text { Perinatal } \\
\text { Motor vehicles } \\
\text { accidents } \\
\text { All other accidents }\end{array}$ & $\begin{array}{l}60 \\
50 \\
40 \\
40 \\
35\end{array}$ & $\begin{array}{l}\text { Cerebrovascular } \\
\text { diseases } \\
\text { Heart diseases } \\
\text { Malignant neoplasms } \\
\text { Avitaminosis and } \\
\text { nutritional } \\
\text { deficiencies } \\
\text { Hypertensive diseases } \\
\text { Enteritis and } \\
\text { diarrhoeal diseases } \\
\text { Diabetes mellitus } \\
\text { Pneumonia } \\
\text { Genito urinary } \\
\text { system } \\
\text { Diseases of arteries, } \\
\text { arterioles and } \\
\text { capillaries }\end{array}$ & $\begin{array}{r}155 \\
125 \\
87\end{array}$ \\
\hline
\end{tabular}

*From Chief Medical Officer's and Ministry of Health Official Reports.

among the 10 leading causes of death in the Englishspeaking islands for many years (Table 1).

\section{Aetiological considerations}

Because of their common ancestry, genetic factors may help to explain the high prevalence of hypertension in blacks in the West Indies and the southern United States (McLean et al., 1974; Boyle, 1970; Moser, 1960), but there is a mosaic of influences governing the expression of this genetic susceptibility (Page, 1982). One important environmental variable is salt. Racial differences in blood pressure have been related to differences in the dietary sodium/potassium ratio (Watson et al., 1980), total salt intake (Dahl and Love, 1954) and to abnormalities of sodium handling (Luft et al., 1977; Forrester and Alleyne, 1981; MacGregor et al., 1982). Teleologically, it can be argued that black persons living in tropical environments have evolved a system of conserving salt as a method of surviving in hot climates and that as a result, on a diet identical to whites, blacks retain more salt and so are more likely to become hypertensive.

There are several observations of biochemical differences between black and white hypertensive 
subjects, including reports of lower plasma noradrenaline (Jones, Hamilton and Reid, 1978) and lower plasma dopamine $\beta$-hydroxylase activity (Levy, Frigon and Stone, 1979) and lower urinary kallikrein (Levy et al., 1977) in blacks compared to whites. However, these findings do not point to a consistently different pathogenetic mechanism, nor have they been easily reproduced. Yet they are often quoted in the literature, serving to over-emphasize their importance and implying fundamental differences in the pathogenesis of hypertension between these 2 ethnic groups rather than to differences in expression of a common abnormality as may be expected from experience with other human diseases.

Even after extensive investigation of hypertensive patients, the majority are found to have essential hypertension and the pattern in Jamaica is similar to that seen elsewhere (Table 2).

TABLE 2. Causes of hypertension at the University Hospital in Jamaica, West Indies (Grell, 1978) and Cleveland Clinic, U.S.A. (Gifford, 1969)

\begin{tabular}{lcc}
\hline & \multicolumn{2}{c}{ Percent of patients } \\
\cline { 2 - 3 } Diagnosis & Jamaica* & Cleveland Clinic $\dagger$ \\
\hline Essential hypertension & $83 \cdot 3$ & $88 \cdot 9$ \\
Renal & $13 \cdot 3$ & $9 \cdot 7$ \\
Coarctation of aorta & $0 \cdot 8$ & $0 \cdot 6$ \\
Primary aldosteronism & - & $0 \cdot 4$ \\
Cushing's syndrome & $0 \cdot 8$ & $0 \cdot 2$ \\
Phaeochromocytoma & 0.8 & $0 \cdot 2$ \\
\hline
\end{tabular}

The report of Laragh (1974) suggested a higher prevalence of 'low renin hypertension' in blacks compared to whites. In black Jamaicans, our own studies showed that the prevalence of low, normal and high renin groups was $31 \%, 45 \%$ and $24 \%$ respectively (Grell, Forrester and Robinson, 1981) and that there was no preponderance of 'low renin hypertension'. It is possible that reports from multiracial societies showing differences in renin levels between blacks and whites may be as much a reflection of socioeconomic and dietary differences, especially differences in chronic salt intake, as it is of differences in the characteristics of the hypertension itself.

\section{Morbidity and mortality}

The most common clinical complications of hypertension in Jamaica and the Caribbean are stroke, renal failure and congestive cardiac failure. This differs from the pattern reported in the U.S.A. (VA Cooperative Study, 1970) (Fig. 3). In our experience, myocardial infarction as a sequelae of hypertension is less common in black West Indians than in white populations, and this racial difference has been noted by Tyroler et al. (1971) in the U.S.A. and Cruick气 shank et al. (1980) in Birmingham, U.K. Adelstei (1978), commenting on the proportional mortalite rates for immigrants to the U.K. born in Common=wealth countries, noted that hypertension was more $\overrightarrow{\mathrm{E}_{\mathrm{S}}}$ common among people of African origin compared to whites or Asians, but that ischaemic heart disease was less common in the group of African origi compared to the other two. There is preliminar evidence from an ongoing study in Trinidad in the West Indies and from clinical experience, that coronary artery disease is more common in Eas Indians than persons of African origin living under identical conditions (CAREC Surveillance Reportw 1977).

Diabetes mellitus is associated with hypertensiofo in $30 \%$ of Jamaican patients, and it has been show that the combination of these 2 problems signifio cantly increases the risk of coronary artery disease of (Ashcroft and Stuart, 1973).

Renal decompensation secondary to the hyperten sive process is common (Fig. 3) and hypertension is the most important single underlying problem pro? ducing renal damage necessitating dialysis in $\mathrm{Ja}_{\vec{O}}$ maica, Barbados and Trinidad. Goss et al. (1969\%, suggested that blacks are more prone to develop renas damage than whites. However, the high prevalence of renal decompensation in black hypertensives may $\$ \overrightarrow{\varepsilon_{0}}$ largely a reflection of the severity of the bloow pressure elevation.

Malignant hypertension is seen in $7 \%$ of hyperten sives admitted to the University Hospital and thepredominant complication is renal failure (Samue and Grell, 1982).

\section{Therapy}

In the early period of the introduction of beta blockers as an anti-hypertensive agent, a clinica? double-blind crossover trial of propranolol in 189 hypertensive Jamaicans showed that there was no. significant difference between this beta-blocker and an inert placebo (Humphreys and Delvin, 1968). The results of this study led to the conclusion that beta옥 blockers were ineffective in black hypertensives. $A^{3}$ recently concluded crossover trial using atenolol and chlorthalidone showed that there was a significan fall in both systolic and diastolic blood pressure withe a small dose of $25 \mathrm{mg}$ of chlorthalidone, but that at the conventional dose of $100 \mathrm{mg}$ atenolol, only the diastolic pressure showed a statistically significan? reduction. However, the combination of atenolol plusw chlorthalidone produced a significant reduction i⿺ both the systolic and diastolic blood pressure which was greater than with either drug used alone (Grell $e$ t al., 1982). While Douglas-Jones and Cruickshank $k^{\circ}$ (1976) showed that atenolol at a dose as low as $50 \mathrm{mg}$ 


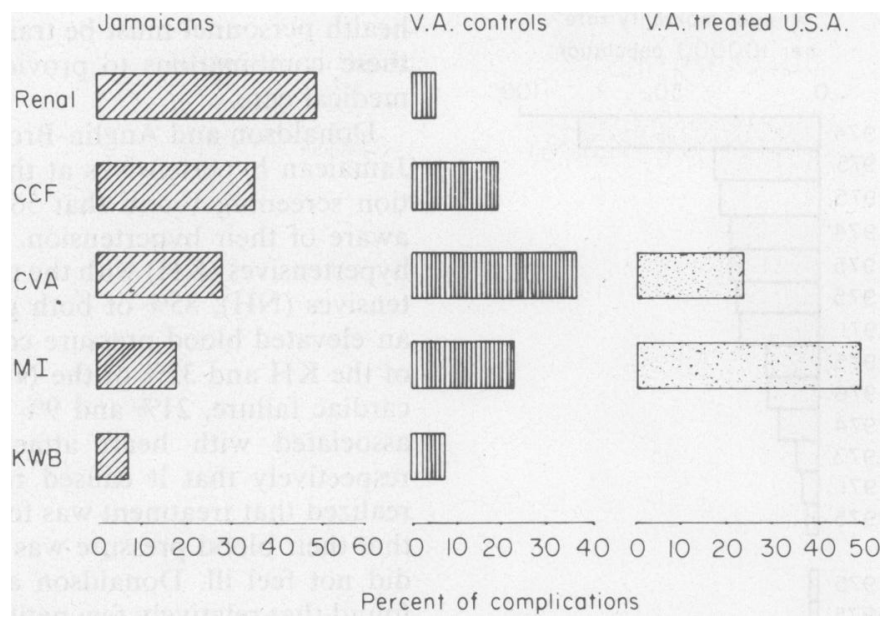

Fig. 3. The pattern of hypertensive complications seen in male Jamaicans* compared with that reported for males in the V.A. study in the U.S.A.† Percentages represent \% of those with complications. *Grell, G.A.C. (1982), †Veterans Administration Cooperative Study (1970) CCF: cardiac failure; CVA: stroke; MI: myocardial infarction; KWB: development of malignant phase hypertension.

daily was effective in lowering the blood pressure of white patients, our experience has been that higher doses are required in black Jamaicans to achieve a successful response (Grell et al., 1981).

It is often stated that blacks are more sensitive to thiazide diuretics than to beta-blockers because they have 'low renin' hypertension, but we were unable to show that the pre-treatment plasma renin activity (PRA) was different in those subjects who responded to $100 \mathrm{mg}$ atenolol alone compared to those who required $200 \mathrm{mg}$ atenolol pulse 50 by chlorthalidone daily to lower their diastolic blood pressure below 95 $\mathrm{mmHg}$ (Grell et al., 1981). It is possible that renin acts mainly as a 'marker' for factors such as the degree of sodium loading, and that it is not by itself of fundamental importance in explaining ethnic differences in responsiveness to drugs.

At the University Hospital of the West Indies, a few well-known anti-hypertensive drugs are selected for general use (Fig. 4). The step-care approach is promoted as it provides a logical, sequential, and effective practical formula through which management can be rationalized (Grell, 1980). Thiazide diuretics are the most commonly prescribed first line drugs as they are cheap and effective. It is recognized that the metabolic side effects including impaired glucose tolerance, hyperuricaemia, and hypokalaemia, are important consequences (MRC, 1981), but the benefit to be derived in a population where the prime responsibility of physicians is in reducing the overwhelming burden of deaths from severe hypertension (Fig. 5) may outweigh the possible disadvantages at this time. Beta-blockers are, however, the drugs of first choice for patients with clinical evidence of ischaemic heart disease or for those at high risk of developing this problem. Experience establishing their efficacy, albeit perhaps sometimes at higher doses than recommended for white patients, has made these agents increasingly useful as step-one drugs in the region.

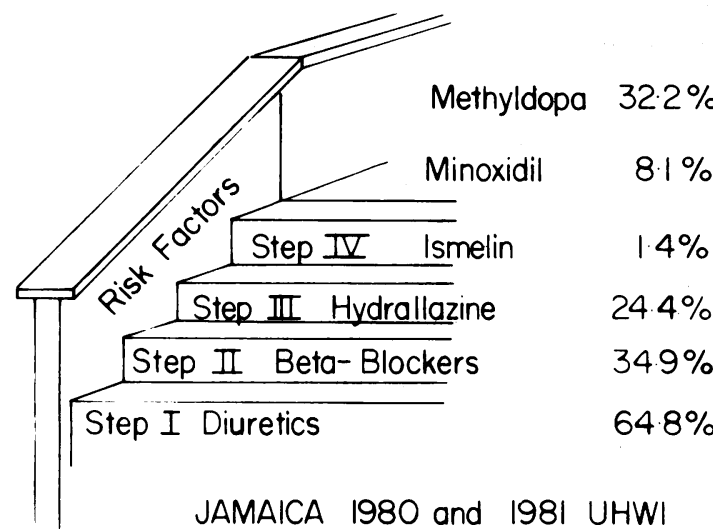

FIG. 4. Drugs used at the University Hospital of the West Indies in the management of hypertension by the step-care approach in 1980 and 1981 .

Minoxidil usage may be over-represented here as a clinical trial of the drug was being carried out during the data collecting period.

Adapted from a paper presented at a symposium on 'Research and Clinical correlates of anti-hypertensive therapy'. Tallahasee, Florida, U.S.A. (1982).

Public and patient attitudes: education, and the health services

In Barbados, Hassell (1976) in a community blood pressure programme undertaken in 1972 showed that only $40 \%$ of hypertensive subjects had been aware of 


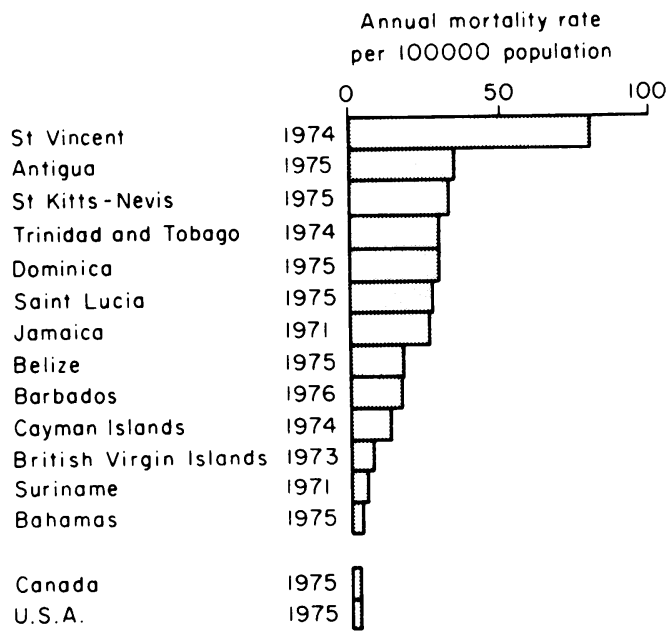

FIG. 5. Age-adjusted death rates per 100000 population from hypertensive disease in some of the English-speaking Caribbean compared to Canada and U.S.A.

(From Health conditions in the Americas, 1973-1976, Scientific Publication No. 364, Pan American Health Organization, Washington, D.C. 1978 with permission of the Editor)

their elevated blood pressure and that only $13 \%$ were on therapy. In a 4-year period of follow-up, compliance was identified as a major problem, and this was related to lack of patient awareness of the importance of blood pressure control, dissatisfaction with clinic facilities, and inability to obtain time off work. Stuart, MacIver and Nicholson (1972) in Jamaica, obtained an $82.5 \%$ clinic attendance rate after 12 months and achieved satisfactory blood pressure control (diastolic blood pressure less than 100 $\mathrm{mmHg}$ ) in $60 \%$ of 81 patients after a mean period of follow-up of 26 months. Stuart's group working from a specialized hypertension clinic felt that their good results reflected the advantages of short waiting times, relaxed atmosphere, minimal staff changes, and the fact that drugs were available to the patients from the clinic itself rather than from an overcrowded central pharmacy.

Dressler (1982) interviewing hypertensive patients in St Lucia found that $50-67 \%$ gave answers indicating their belief in a personalistic cause (a result of intervention of human, non-human or supernatural agents) rather than a cause as a result of natural forces for their illness. However, many held the view that anxiety and tension may be important in its causation. Most subjects interviewed accepted that persons with high blood pressure must always take pills $(92 \%)$, yet $52 \%$ felt that eating cucumber was good for hypertension and $82 \%$ felt that eating green paupau was also effective. These findings demonstrate that in West Indian society, personalistic, naturalistic, and modern medical beliefs coexist, and health personnel must be trained to utilize optimally these combinations to provide effective delivery of medical care.

Donaldson and Anglin-Brown (1982) in a study of. Jamaican hypertensives at the time of pre-immigra tion screening found that $56 \%$ had been previousl $\vec{b}$ aware of their hypertension. Comparing the knowf hypertensives $(\mathrm{KH})$ with the newly discovered hyper $\overline{\bar{m}}$. tensives (NH), $85 \%$ of both groups were aware tha an elevated blood pressure could cause strokes, $55 \%$ of the $\mathrm{KH}$ and $32 \%$ of the $\mathrm{NH}$ that it was a cause of cardiac failure, $21 \%$ and $9 \%$ respectively that it was associated with heart attacks, and $13 \%$ and $6 \%$ respectively that it caused renal failure. Only $20 \%$ realized that treatment was for life and $76 \%$ believes that their blood pressure was normal as long as the did not feel ill. Donaldson and Anglin-Brown alse found that relatively few patients cited health profesco sionals (48\% the doctor, $23 \%$ the nurse) as their majoco source of information about hypertension reflecting an inadequate emphasis on patient education and/of poor comprehension of the material presented, 3 problem which needs to be rectified in current programmes.

The non-medical members of the health team in the Caribbean, as elsewhere, have a valuable role to play in patient and public education and in the totas management of hypertensive patients. With fict development of the primary health care serviees nurse-practitioners are assuming an increasing sponsibility for the management of hypertensity patients in the West Indies. In Barbados, pharmacist run a screening service for detecting high bloo pressure and have developed a referral system to general practitioners for persons so diagnosed. The use of community health aids for monitoring the blood pressure of patients in their home environ 3 ment, as has been initiated in some West Indiat territories, may serve to re-enforce the importance of continuous blood pressure control and may be effective in improving drug compliance and clini attendance.

Research experience in the West Indies should help to provide valuable information about the pattern of hypertension in a black population and may supply important lessons applicable to otheo developing countries with regards to the management of this disease.

\section{References}

Adelstein, A.M (1978) Current vital statistics: methods an interpretation. British Medical Journal, 2, 983.

ANTIA, A.U., MAXWELl, R., GOUGH, A. \& AYENI, O. (1980) Arteriæ blood pressures in Jamaican children of Negro descent. West Indian Medical Journal, 29, 110.

ASHCROFT, M.T. \& STUART, K.L. (1973) Acute myocardial infar\& tion in the University Hospital, Jamaica, 1968-1970. West Indian Medical Journal, 22, 60. 
BOYLE, E. JR. (1970) Biological patterns in hypertension by race, sex, body weight, and skin colour. Journal of the American Medical Association, 213, 1637.

CAREC SURVeIllanCe RePORT (1977) Chronic non-communicable diseases in Trinidad, 3, 1.

Cruickshank, J.K., Beevers, D.G., Osbourne, V.L., Haynes, R.A., CORLETT, J.C.R. \& SElBY, S. (1980) Heart attack, stroke, diabetes and hypertension in West Indian, Asians and Whites in Birmingham, England. British Medical Journal, 281, 1108.

DAHL, L.K. \& LOVE, R.A. (1954) Relation of sodium chloride intake to essential hypertension. Federal Proceedings, 13, 426.

Douglas-Jones, A.P. \& Cruickshank, J.M. (1976) Once daily dosing with atenolol in patients with mild or moderate hypertension. British Medical Journal, 1, 990.

DonAlDSON, E.K. \& ANGLIN-Brown, B. (1982) Patient concepts in hypertension. 27th Scientific Meeting Commonwealth Caribbean Medical Research Council. Abstract, p. 34.

DRESSLER, W.W. (1982) In: Hypertension and Culture Change: Acculturation and Disease in the West Indies. Redgrave, South Salem, N.Y., U.S.A.

ForRester, T. \& Alleyne, G.A.O. (1981) Sodium, potassium, and rate constants for sodium efflux in leucocytes from hypertensive Jamaicans. British Medical Journal, 283, 5.

GIFFORD, R.W. (1969) Evaluation of the hypertensive patient with emphasis on detecting curable causes. Millbank Memorial Fund Quarterly, XLVII, 170.

GoSS, L.Z., ROSA, R.M., O'Brien, W.M., AYERS, C.R. \& WOOD, J.E. (1969) Predicting death from renal failure in primary hypertension. Archives of Internal Medicine, 124, 160.

GrELL, G.A.C. (1978) Clinical aspects of hypertension in Jamaica. West Indian Medical Journal, 27, 231.

GreLL, G.A.C. (1980) Clinical aspects of the management of hypertension in the Caribbean. West Indian Medical Journal, 29, 163.

Grell, G.A.C., Alleyne, G.A.O., Robinson, H.M. \& ANDERSON, N. (1981) Treatment of Jamaican hypertensives with atenolol and chlorthalidone. West Indian Medical Journal, 30, 124

Grell, G.A.C., ForRester, T.E. \& Robinson, A.M. (1981) Renin levels in hypertensive patients in Jamaica. West Indian Medical Journal, 30, 30.

Grell, G.A.C., Forrester, T.E., GibBs, P. Anderson, M. \& DOUBLAS, R. (1982) Diuretics versus beta-blockers in the treatment of black hypertensives. 27th Scientific Meeting of the Commonwealth Caribbean Medical Research Council (CCMRC). Abstract, p. 45 .

Grell, G.A.C. (1982) John Hayes Memorial Symposium, Port-ofSpain, Trinidad.

GRELL, G.A.C. (1982) The problem of hypertension in the Caribbean. Caribbean Community Secretariat CMH Document 82/8/40. Eighth Meeting of the Conference of Ministers Responsible for Health, Bridgetown, Barbados.

HASSELl, T. (1976) Hypertension clinic in the general population (Barbados). In: Synopsis of a workshop on hypertension in the Caribbean. Abstract, p. 13, Barbados, November 15-16.

HUMPHREYS, G.S. \& DELVIN, D.G. (1968) Ineffectiveness of propranolol in hypertensive Jamaicans. British Medical Journal, 2, 601.

HDFP (HyPertension Detection and Follow-up Program) COOPERATIVE GROUP (1977) Race, education and prevalence of hypertension. American Journal of Epidemiology, 106, 351.
JoNeS, D.H., Hamilton, C.A. \& Reid, J.L. (1978) Plasma noradrenaline, age and blood pressure in a population study. Clinical Science and Molecular Medicine, 55, 73.

LARAGH, J.H. (1974) Hypertension Manual: Mechanisms, Methods, Management. Yorke Medical Books, Dun-Donnelley Publishing Corporation, New York.

Levy, S.B., Lilley, J.J., Frigon, R.P. \& Stone, R.A. (1977) Urinary kallikrein and plasma renin activity as determinants of renal blood flow: the influence of race and dietary sodium intake. Journal of Clinical Investigation, 60, 123.

LEVY, S.B., FIRGON, R.P. \& STONE, R.A. (1979) Plasma dopamine beta-hydroxylase activity and blood pressure variability in hypertensive man. Clinical Endocrinology, 11, 187.

LufT, F.C., Grim, C.E., Higgins, J.T. \& Weinberger, M.H. (1977) Differences in response to sodium administration in normotensive white and black subjects. Journal of Laboratory and Clinical Medicine, 90, 555.

MacGregor, G., Fenton, S., Alaghbank-Zadeh, J., MarKANDU, N., Roulston, J.E. \& DE WARDENER, H. (1982) Evidence for a raised concentration of a circulating sodium transport inhibitor in essential hypertension. British Medical Journal, 283, 1355.

MClean, C.J., Adams, M.S., Leyshorn, W.C., Workman, P.L., REED, T.E., GeRshowITZ, H. \& WeITRAMP, L.R. (1974) Genetic studies on hybrid population. III. Blood pressure in an American black community. American Journal of Human Genetics, 26, 614.

MialL, W.E. \& CoCHRANE, A.L. (1961) The distribution of arterial pressure in Wales and Jamaica. Pathology \& Microbiology, 24, 690.

MOSER, M. (1960) Epidemiology of hypertension with particular reference to radical susceptibility. Annals of the New York Academy of Science, 84, 989.

MRC (MEdical Research COUNCIL) Working PaRTy ON MILD TO MODERATE HYPERTENSION (1981) Adverse reactions to bendrofluazide and propranolol for the treatment of mild hypertension. Lancet, ii, 539.

PAGE, I.H. (1982) The mosaic theory 32 years later. Hypertension, 4, 177.

SAMUEL, E.H.C. \& Grell, G.A.C. (1982) Malignant hypertension at the University Hospital. 27th Meeting of the Commonwealth Caribbean Medical Research Council (CCMRC). Abstract, p. 15.

Sever, P.S., PearT, W.S., Meade, T.W., Davies, B. \& Tunbridge, R.D.G. (1978) Are racial differences in essential hypertension due to different pathogenetic mechanisms? Clinical Science and Molecular Medicine, 55, 383.

StUART, K.L., MACIVER, C. \& Nicholson, J.A. (1972) Outpatient treatment trial of mild and severe hypertension. British Medical JQurnal, 2, 21.

Tyroler, H.A., Heyden, S., Bartel, A., Cassel, J., Cornoni, J.C., JAMES, C.G. \& KLEINBANM, D. (1971) Blood pressure and cholesterol as coronary heart disease risk factors. Archives of Internal Medicine, 128, 907.

VETERANS ADMINISTRATION COOPERATIVE STUdy Group ON ANTIHYPERTENSIVE AGENTS (1970) Journal of the American Medical Association, 213, 1143.

WATSON, R.L., LANGFoRD, H.G., ABernathy, J., BaRnes, T.Y. \& WATSON, M.J. (1980) Urinary electrolytes, body weight and blood pressure. Pooled cross-sectional results among four groups of adolescent females. Hypertension, 2 (Suppl. 1), 93. 